\title{
Inhaltsverzeichnis
}

Verzeichnis der aufgenommenen Entscheidungen . . . . . VII

\section{Recht der Schuldverhältnisse}

\section{Toil 5}

\section{Besonderer Teil}

Kauf (Fortsetzung) •

Schenkung . . . . . . . . . . . . . . . . . . . 298

Miete und Pacht . . . . . . . . . . . . . . . . . 357

Sachregister . . . . . . . . . . . . . . . . . . 385 

. 